\title{
TRADITIONAL LEADERSHIP AND CORRUPTION IN PRE-COLONIAL AFRICA: HOW THE PAST AFFECTS THE PRESENT
}

\author{
Benson O. Igboin 1 \\ Department of Religion \& African Culture \\ AdekunleAjasin University, Akungba-Akoko, Ondo State, Nigeria \\ bensonigboin@gmail.com
}

\section{ABSTRACT}

There are two popular schools of thought about corruption in pre-colonial Africa the Afrocentric view and that of decolonisation. The latter argues that there were corrupt practices broadly defined in pre-colonial Africa, since corruption is a universal concept. It further argues that many traditional African leaders were and are still corrupt, independent of colonial influence. Therefore, they could not be insulated from corruption. The Afrocentric school argues that pre-colonial African leaders were responsible and responsive to their subjects and avoided corruption as much as possible. It maintains that traditional African leaders in the pre-colonial period could hardly be said to be corrupt, because of the communal spirit that guided their operation. This paper critically examines both views and posits that corrupt practices as a human rights violation were present in pre-colonial Africa and still resonate in post-colonial Africa.

Keywords: Corruption; pre-colonial Africa; post-colonial Africa; Afrocentric; decolonialisation; traditional leadership

1 Benson O. Igboin is an academic associate of the Research Institute for Theology and Religion, University of South Africa, Pretoria. This paper presented at the conference on 'Accountable Leadership and Sustainability in Africa: Religion, Democracy and Civil Society', University of South Africa (UNISA) 21-24 April 2015

\section{UNISA $\cong$}

Studia Historiae Ecclesiasticae Volume 42 | Number 3 | 2016 | pp. 142-160 https://upjournals.co.za/index.php/SHE
DOI: http://dx.doi.org/10.17159/2412-4265/2016/228 Print ISSN 1017-0499 | Online 2412-4265 (C) 2016. Studia Historiae Ecclesiasticae 


\section{INTRODUCTION}

Africa's failure to develop in comparison with other developed continents of the world, in spite of its human and natural resources, has elicited lively scholarly discussions. In fact, during the International Interdisciplinary Conference on politics, probity, poverty, and prayer: African spiritualities, economic and socio-political transformation(organised by the University of Edinburgh, University of Ghana and Trinity College, Ghana held at the Centre for African Wetlands, University of Ghana, Legon from 21-23 October 2013), Afe Adogame, the convener, challenged the conferees to look back into the past, which most people felt should be interrogated further in an attempt to locate the source of corruption in contemporary African nations. It was also pointed out then that there was the need to underscore the extent to which pre-colonial traditional leadership was accountable to the people. The essence of that discussion was to find out whether pre-colonial African communities were really corruption-free, or whether they were the precursors of the inveterate corruption that has come to define leadership in the continent in the post-colonial era. In other words, can we locate the source of today's widespread corruption in the past or was the past completely different from the present? What actually was the influence of colonialism on the perception of corruption in the pre-colonial era? Can Africans continue to romanticise the past, painting it in such a flowery innocence? If not, what exactly can we define to be corruption then? This paper is therefore a response to that clarion call. It is not aimed at proffering solutions per se to corruption, but it is an attempt to establish the fact that what may be defined as corrupt practices today, could have existed independently in Africa before the advent of colonialism. And many of them are still practised in post-colonial Africa.

\section{Traditional leadership}

In this paper, the focus is not delving into the controversies that characterise what is understood or regarded as traditional leadership. The reason is that the term 'tradition' is a problematic one. Many things that hide under the toga of tradition, as conceptualised in modern society, may not successfully pass the test of being traditional. For instance, according to Adewumi and Egwurube:

...the group referred to as traditional leaders/rulers or tribal leaders/rulers are individuals occupying communal political leadership positions sanctified by cultural mores and values, and enjoying the legitimacy of particular communities to direct their affairs...Their basis of legitimacy is therefore tradition, which includes the whole range of inherited culture and way of life; a people's history; moral and social values and the traditional institutions which survive to serve those values. ${ }^{2}$

2 Cited in Keulder 2008.Traditional leadership. In State, society and democracy: A reader in Namibian Politics. Edited by C.Keulder (Gamsberg: Macmillan, 2008), 152. 
In contemporary Africa, the basis and legitimacy of 'traditional' leadership may not strictly be tradition, not only because the kings are now mostly being officially installed by modern government but also that the tradition relied upon has continued to change and accommodate newer development contrary to the understanding of what tradition ought to be. How traditional is a traditional ruler who does not believe in African Indigenous Religion, who instead professes and practises either Christianity or Islam? Worse still, how traditional is a traditional ruler who has to depend on an interpreter to communicate with his subjects? How would contemporary Africans classify a traditional ruler who personally collects rates from taxi drivers in the pretext of maintaining roads leading to his palace? Do contemporary Africans refer to a traditional ruler as one who goes from one birthday party to another social party, or playing partisan politics? In no time, all these seemingly abhorrent practices would be transmitted as revered traditions, which the next generation would defend as authentic. ${ }^{3}$ What is therefore referred to as traditional leadership in contemporary Africa, cannot be so defined in the context of pre-colonial Africa. Rather it would be better to call them customary leaders because customs are derived from tradition but respond more quickly to emerging challenges than tradition. ${ }^{4}$

\section{Deconstructing corruption}

Corruption is a problematic and elusive concept; that is why many scholars deliberately avoid defining it. This is so because an act that some may think to be corrupt may successfully pass through the nozzle of legal process. If it does, the moral perspective naturally springs forth. On the other hand, a morally abhorrent act may not be so regarded by law. But a successful deconstruction of it can help in an attempt to draw a link between the past and the present.

As a legal phenomenon, corruption is an act that contravenes the law. According to Girling, corruption is 'illegal behaviour's associated with abuse of an office. Girling further argues that corruption may be a legal but an illegitimate behaviour. By this he means that an office holder may not directly be involved in corrupt practices but creates its possibilities. For instance, it is legal for a governor of a state to give employment to the citizens of the state. Siblings and friends of the governor are citizens of the state as well as others not related to her/him. If the governor employs

3 Igboin2013.Cosmotheandrism and traditional African leadership: The future left behind? Paper presented at the International Conference of African Studies, on the theme: Revisiting the First International Congress of Africanists in a globalised world. Institute of African Studies, University of Ghana, Legon 24-26 October, 2013; Igboin, 2014a.Revisiting the basis of the metaphysics of ancestorship in contemporary Africa. In Death and life after death in African philosophy and religions: A multidisciplinary engagement. Edited by DanoyeOguntola-Laguda (Harare: Africa Institute for Culture, Dialogue, Peace and Tolerance Studies, 2014) 79-97.

$4 \quad$ Keulder 2008, 152.

5 Girling 1997.Corruption, capitalism and democracy(London: Routledge, 1997), 10. 
her/his friends and siblings, no corruption may have been done as they are entitled to it by reason of being citizens. But the use of the government official's position to give jobs, appointments and contracts to these people at the expense of other citizens, is illegitimate even though it is not illegal to give jobs to citizens. There is the act of perversion of public office to serve self-interest. This act is what sections of the public acknowledge as corruption on a broader spectrum. ${ }^{6}$

On the moral plane, corruption is thought to be unacceptable behaviour that has consequences on the enactor, the victim and the society at large. In fact, corruptio, the Latin etymological derivative, means 'moral decay, wicked behaviour, putridity or rottenness'. ${ }^{7}$ It is argued that corruption is a violation of the rights of what others are morally and legally entitled to in order to enrich oneself. Even though the state agency or law may be weak or compromised sometimes in the process of legally evaluating a corrupt practice, and an accused may be inadvertently or deliberately discharged and acquitted, such acquittance does not translate into moral exoneration. In other words, even though there are no recognised public moral tribunals to try corrupt practices like the law courts, the morality of the violation of public law can still be established. Akpotor suggests that corruption as an immoral behaviour is a 'privileged crime' ${ }^{8}$ committed by government officials and covered by compromised civil societies. It is a crime against the people who are 'invaded' and victimised. The simple reason that corruption depicts aggressor-victim dialectics justifiably means that it is a highly moral issue.

DeSwardt identifies the greatest casualties of corruption as "vulnerable and marginalised - women, children and minority groups - who often suffer corruption's harshest consequences'. ${ }^{9}$ As a result of the magnitude of the casualties, discussion on corruption 'is no longer taboo' ${ }^{10}$ as it used to be. In fact, as it is being witnessed in many African countries, corrupt people establish their hold on power so that they can continue to dictate the pace. ${ }^{11}$ The International Council of Human Rights Policy also observes as follows:

Those who commit corrupt acts will attempt to protect themselves from detection and maintain their positions of power. In doing so, they are likely to further oppress people who

6 Girling 1997, 11.

7 International Council on Human Rights Policy and Transparency International, Corruption and Human Rights: Making the Connection (Switzerland, International Council on Human Rights Policy, 2009), 15.

8 Akpotor 2003. Corruption: The civil society and government. In Philosophy and politics: Discourse on values, politics and power in Africa. Edited byDukor (Lagos: Malthouse Press Ltd, 2003), 355.

9 De Swardt in Foreword, International Council on Human Rights Policy and Transparency International, Corruption and Human Rights: Making the Connection, v

10 International Council on Human Rights Policy and Transparency International, 1.

11 Onimhawo and Igboin 2008. ONANISM: A Moral Evaluation of Political Power Retention in Nigeria, Monograph series 1. 
are not in positions of power, including most members of the groups listed above. The latter tend both to be more exploited, and less able to defend themselves: in this sense, corruption reinforces their exclusion and the discrimination to which they are exposed. ${ }^{12}$

When we juxtapose the legal and moral perspectives thus argued above, we can begin to situate corruption within the frames of human rights. This interesting aspect of the concept encapsulates both strands - legal and moral. The fact that international laws and conventions and national laws too have not yet recognised the 'justiciability' of corruption as a violation of the rights of the 'vulnerable' does not vitiate the obvious reality that they are being violated.

The commitments that states have made to combat corruption have run parallel with their commitments to promote and respect human rights. However, international anti-corruption conventions rarely refer to human rights; and major human rights instruments rarely mention corruption. The absence in international law of direct references to the links between corruption and human rights mirrors the way these two issues are discussed politically, but is at odds with experience: in reality many links are evident. ${ }^{13}$

The above shows that corruption violates the rights of those who are affected by it, regardless of time and space. In other words, if we argue that there were corrupt practices in pre-colonial Africa it would naturally mean that the rights of those affected negatively were violated. This is so despite the fact that the issue of human rights advocacy might not have been as intense as it is today. If corruption violated the rights of those affected then, it also follows that it does today. If this is so, corruption cannot have a positive contribution to society, contrary to Ogungbemi's claim. According to Ogungbemi, corruption is positive when its results satisfy the greatest number of beneficiaries but negative when its results do not benefit the greatest number of beneficiaries. He exemplified that if someone embezzles public funds and builds a cottage hospital for his/her community using such funds, it is positive corruption. The hospital does not only take care of the people's health challenges but also gives employment to them. On the other hand, if a person embezzles public funds and refuses to use part of the funds to help the people, it is negative corruption. ${ }^{14}$

Ogungbemi's utilitarian argument does not only run counter to moral deontological-ethical imperatives, but also calls altruistic actions to question. The relevant questions to ask include: Should privileged people corrupt the system in order to provide social amenities for the citizens? Should such acts of corruption be recommended for all those in positions, even if it is argued that some good may come out of it? Should corruption become a duty for every person in human society? If it is so, how would that affect the moral repugnance associated with corruption in society? Does it not imply that the fight against corruption is futile if it is thought

12 International Council on Human Rights Policy and Transparency International, 9.

13 International Council on Human Rights Policy and Transparency International, 3.

14 See Ogungbemi 2007.Philosophy and development(Ibadan: Hope Publications, 2007), 46. 
that it results in some good for human society? How do we measure the positive contributions corruption can make when the corrupt individual refuses to declare the total amount of what he/she corruptly acquired from the people? Is it possible to measure the influence such public good would have made if it had not been corrupted? Should we argue that by providing some good from corrupt proceeds that the corrupt person is altruistic, and should therefore be regarded as a philanthropist and praised? In either type - negative and positive - there is a gross violation of the rights of the general citizenry who should have had access to what the funds were budgeted for ab initio. But did such corruption happen in pre-colonial Africa? This leads us to determine whether or not there was corruption in pre-colonial Africa.

\section{Determining corruption in pre-colonial Africa}

Some have sounded a caveat that in investigating corruption in pre-colonial Africa, there is the need to exercise some restraint defining and differentiating corruption in post-colonial categories from the pre-colonial thinking about it. This is because corruption is a transient term or phenomenon; expanding and discarding. It expands as society comes in contact with new development and challenges not contained in its law books or convention; discarding in the sense that there are some acts which in the course of time are regarded by the same society as less corrupt or totally corruption-free, appropriated and appreciated. This can be seen in the development and application of theories to admit or oust a particular act from corruption. The nature of society also determines what should be regarded as corruption at a particular time. ${ }^{15}$

Despite this standpoint, Norris observes 'that these developments have another, more critical and progressive aspect [which] may be judged from the virulent attacks heaped upon them by conservative defenders of old corruption in the name of tradition or "commonsense" values' ${ }^{16}$ In other words, some researchers may want to romanticise the past and believe that some actions, viewed within the context of pre-colonial Africa, cannot pass as corruption. Tradition, as is commonly believed, cannot be wrong since it is the guide for a people who live by it. The sacrality of tradition thus suggests that anything done within its frames cannot be challenged within that system that adopted it ab initio. But other things done outside the cover of tradition could be subjected to trial and possible punishment. ${ }^{17}$ Williams holds this position, for according to him 'it is difficult to find the word corruption in most ethnic languages, because what may be considered corrupt practices in the

15 Williams 2007. Can our culture and traditions overcome corruption? CBAAC Occasional Monograph No. 1, Lagos, 2007, 31.

16 Norris 2010.Philosophy of law. In A dictionary of cultural and critical theory (2nd edition).Edited by M. Payne and J.R. Barbera. (UK: Blackwell Publishing, 2010), 409-410.

17 Igboin 2013.Cosmotheandrism and Traditional African Leadership: The Future Left Behind? 
past might be considered abuse of power today'. ${ }^{18}$ As will be substantiated shortly, Williams does not maintain a consistent defence of this argument. In the meantime, the most important point he has made here is not that there could not have been a direct translational word for corruption in most African communities (not in all), but that corrupt practices certainly could have existed.

The question whether there was corruption in pre-colonial Africa cannot be answered straightforwardly. The reason is not far-fetched. This paper develops two schools of thought that argue for and against the position. The first is the Afrocentric and the second is the decolonisation school. The Afrocentric school holds the argument that pre-colonial Africa was not corrupt; it was a near perfect community. This school also believes strongly that contemporary Africa does not have to just borrow from the past, but may have to adopt wholly the pre-colonial African past as a response to the negative effects of colonialism. According to this school, Africans were guided by religious and moral rules which the members of the community lived by. The rules of the community ensured that everybody was his/her brother/ sister's keeper. ${ }^{19}$ As a result, acts of corruption could not have existed, since what affected a member of the community was believed to have affected all members in the communal system.

Ehiabhi, holding an Afrocentric view, argues that using a post-colonial definition of corruption to evaluate the activities of the pre-colonial era would mean that such action as the giving of fabulous gifts would mean corruption. He further posits that indigenous African religion played a critical role in ensuring that there was social sanity. Since the ancestors were believed to be very active in the administration of community life, the fear of repercussion for doing evil was strong enough to prevent occurrences of corrupt practices. ${ }^{20}$ Gyekye also talks about 'embarrassing' a gift offer, which in post-colonial reckoning could be regarded as bribery. He points out that if a gift was too much, the recipient could return it. ${ }^{21}$ Antwi-Danso gives a concrete example of Mansa Kankan Musa, the King of Mali empire, who in 1324 on a pilgrimage to Mecca went with '60 000 people - 12000 servants, 500 slaves (each carrying a golden staff), and 80 camels carrying more than two tons of gold' ${ }^{22}$ which he gave to his hosts as gifts. These kinds of gifts were viewed as a demonstration of

18 Williams 2007, 31.

19 Igboin 2015. Afrocentrism: Recalling the will of the past for the future. Paper presented at the Conference organised by the Faculty of Letters and Social Sciences, University of Douala, Republic of Cameroon on the theme: A Young Commonwealth, Cultural Heritage and Commonwealth Values, 11-14 March, 2015.

20 A personal discussion with Dr Simon O. Ehiabhi, Head of Department, History and International Studies, Adekunle Ajasin University, Akungba-Akoko, Nigeria on 8 April 2015.

21 Gyekye 2003. Political corruption: A philosophical inquiry into a moral problem.In Philosophy and politics. Edited byDukor, 407.

22 Antwi-Danso 2005. Development theory: Conjectures and refutations in the African context, peper delivered at the 10th International Conference of the Seminary of All Saints, Ekpoma, Edo State, Nigeria, 25-29 October, 2005, 5. 
over-generosity. In Cairo, Egypt, Musa doled out so much gold as gifts, that it led to the collapse of the gold market; thus causing serious economic crisis. The economic recession that followed Musa's action took more than a decade to recover. ${ }^{23}$ With his lavish spending and generosity in Cairo and Mecca, he ran out of money and had to borrow at usurious rates of interest for the return trip. ${ }^{24}$

Although the Afrocentric school might praise Musa's generous disposition and the political recognition that followed the massive pilgrimage, it is necessary to unravel the economic enervation that it could have caused his empire. If he had to borrow money to return back home, it would suggest that he probably was not a good economic manager. In fact, in contemporary African society, such a person may be charged for money laundering for taking so much money out of his country.

Vengeyi argues that 'over-hospitality' of African leadership brings hardship to its citizens. Writing about King Munhumutapa of pre-colonial Zimbabwe, Vengeyi queries:

...one wonders in what state of mind this whole king was to submit his own people to be violated as sex slaves? What did the king hope to gain by giving Fr. Silveira these vast amounts of gold dust, a hundred head of cattle and female slaves? While it may be understood that the King had been told that Fr. Silveira was a high official of the Portuguese Empire, therefore he hoped to gain from the relationship; however it is unforgivable to submit his own people as sex slaves. ${ }^{25}$

In comparison with post-colonial reality, Vengeyi observes correctly that whenever a Western leader is visiting most African states, the hosts may declare a public holiday, organise different cultural troupes to entertain the guest right from the airport, take the guest to visit important institutions, including defence and security, and in many instances bend rules and violate laws to favour the guest to invest in their countries. But none of such is ever done when any African leader visits the West. ${ }^{26}$

In pre-colonial Africa, no king was queried or called to account for the kingdom's resources or taxes because he was simply above the law. Kings were regarded as the representatives or viceroy of God on earth. Since God could not be questioned, the people believed that his representatives could not be questioned either. In fact, 'a king's powers are unlimited. He rules over the life and the property of every person living in his country' ${ }^{27}$ In some cases, a king could marry someone's wife

23 See Musa, Mansa (1280-1337). The black past: Remembered and RECLAIMED, retrieved from http://www.blackpast.org/gah/musa-mansa-1280-1337(accessed on 21 October 2015).

24 See Musa Mansa,http://www.blackhistorypages.net/pages/mansamusa.php(accessed on 21 October 2015).

25 Vengeyi 2015. Fr. Gonzalo da Silveira'sevangelisation strategies as roots for disempowerment: Lessons for Africa from Zimbabwe's history. Journal of African Culture and International Understanding 11(January-June 2015): 27-28.

26 Vengeyi 2015, 28.

27 Keulder 2008, 156. 
without challenge from the husband. A king had absolute control over the army, priest-hood and the polity. ${ }^{28}$ Williams ${ }^{29}$ corroborates this argument when he posits that many African 'kings and queens... squandered vast amounts of natural wealth on wars, kings and palaces. They were like gods with absolute power which corrupted absolutely'.

Ali, former chairman of Peoples Democratic Party (PDP) in Nigeria, elucidates the point that pre-colonial African kings were unquestionable. According to him, no citizen had the rights or effrontery to accuse a king of wrong-doing. He argues that the powers kings wielded then should also resonate in modern democratic practice in post-colonial Africa. He says: '[T] he way democracy works in America is different from the way it works in France, in Britain etc. Because their cultural context have (sic) had something to do with it...don't waste your time bringing democracy if you are not ready to take the cultural context into the equation. ${ }^{30}$ The cultural equation Ali implies is that an African king does not relinquish the throne: he dies there and never lives to be probed. This trait has been commonplace in democratising Africa where presidents want to continue in power even beyond what the constitutions allow. Ali also indicates that there are no differences between the presidents or kings in an African setting. ${ }^{31}$ Williams points out that the reason why traditional rulers have lost the power to fight against corruption in post-colonial Africa is that most of them are politically partisan and 'have become part of the other corrupt public realm' ${ }^{32}$ This is what the Oba of Lagos assumed recently when he spoke as the voice of God in cursing the Igbo, should the latter vote against the former's preferred gubernatorial candidate in Lagos, during the Nigeria election in April 2015.Akiolu claims that he was speaking the mind of God and the ancestors. He adds that anyone who goes against his choice would die in the lagoon within seven days. He declares:

...by the grace of God, I am the owner of Lagos for the time being. This is an undivided chair. The palace belongs to the dead and those coming in the future...It is God who chose him [that is, the APC's governorship candidate, Ambode]. And God who chose him will be with him. It is God who decided...the outcome of the polls...So they do my bidding. And that is the bidding of the ancestors of Lagos and God. ${ }^{33}$

In pre-colonial Africa, Akiolu's judgement would have been taken without disputation. The Oba assumes that since he is the 'traditional' ruler of Lagos,

28 Keulder 2008, 156.

29 Williams 2007, 9.

30 Cited in Onimhawo and Igboin 2008.ONANISM: A moral evaluation of political power retention in Nigeria. Monograph series 1, 2008.

31 Igboin 2011.Political onanism and scepticism in a democratic country. LUMINA, 22(1 March 2011): 234-249.

32 Williams 2007, 29.

$33 \mathrm{http} / /$ korrectgossips.com/gossips/if-you-dont-vote-ambode-thats-your-end-oba-of-lagos-warnsigbos/ 
whatever he says is sacrosanct. But times have changed. When the curse went viral in the social media, he was forced to explain that he did not mean what he said. The Igbo fought back, alleging that their fundamental human rights to vote freely for their chosen candidate were being infringed upon. However, some Yoruba defended their Oba as well, claiming that he spoke the mind of the ancestors. The Igbo, they argue, should respectfully follow the dictate of the Oba since they are living within his territory. ${ }^{34} \mathrm{But}$ that does not settle the reverse of the case: what would happen to the curse if the Igbo eventually voted for the Oba's candidate, or what would be the fate of Lagos people who voted against the Oba's choice? When eventually the Oba's anointed candidate for the governorship election won, the Oba might arguably feel justified that he indeed spoke the mind of the ancestors.

Hrituleac maintains that it is hard to say that pre-colonial Africa had serious issues with corruption. In fact, she claims that "corruption was introduced by England and France and other colonial rulers by monetary economy, cash taxation and the use of the divide and impera (sic) rule method' ${ }^{35}$ On the contrary 'colonization obstructed the internal process of state formation and the development in Africa and left scars of corruption and political instability' ${ }^{36}$ But she recognises that traditional African leaders were actively involved in slave trade in which they commodified their subjects and sold them off cheaply. ${ }^{37} \mathrm{Nunn}$ explicitly writes in this regard:

The model suggests that prior to European contact, societies within Africa were located in a stable equilibrium without rent-seeking behavior. Following European contact, these societies would have remained in this equilibrium, had it not been for the large amount of colonial extraction, which caused the zero rent-seeking equilibrium to disappear and a subsequent movement to a stable high rent-seeking equilibrium. Even after the period of extraction has ended, the past effects of extraction are still felt, because the society has been permanently moved to a new equilibrium characterized by high levels of corruption, rentseeking, and insecure property rights. This is the legacy of colonialism. ${ }^{38}$

The second school of thought is the Decolonisation school. This school believes that the pre-colonial African communities contributed immensely to global development. However, as a human society, pre-colonial Africans were not corruption-free. According to this school, community life does not mean that people's rights were not trampled upon. Essentially, individuals' rights and achievements were subsumed under community life. Taking a closer look at communalism, those at the top of the

34 http://korrectgossips.com/gossips/if-you-dont-vote-ambode-thats-your-end-oba-of-lagos-warnsigbos/

35 Hrituleac 2011. The effects of colonialism on African economic development: A comparative analysis between Ethiopia, Senegal and Uganda. MSc dissertation submitted to Aarhus University, Business and Social Sciences, 44.

36 Hrituleac 2011, i.

37 Hrituleac 2011, 20.

38 Nunn 2003. The legacy of colonialism: A model of Africa's underdevelopment. Department of Economics and Institute for Policy Analysis, University of Toronto, 24. 
hierarchy of the community leadership usually gained most from the cumulative efforts of individuals, even though in many cases the community might not have contributed to the process of such success in the first instance. An example can be drawn in Achebe's Things fall apart in which Nnoka, the wretched father of Okonkwo, was stigmatised by his son, the community and even the gods. On the other hand, Okonkwo, his son, by defeating Amalinze the cat, became a community person, whose fate was communally severed from his so-called lazy father and recognised as the hero of the community. ${ }^{39}$

In addition, when one studies African languages, it would be discovered that there are a plethora of registers that depict acts of corruption independent of colonial contact. In other words, there are African indigenous linguistic evidences that corruption existed in pre-colonial Africa. A careful analysis of many African words would show that certain actions enacted by Africans in the past were corrupt. The same could be applied to stories which are narrated for didactic purposes. In fact, many African stories clearly depict the fact that they are meant to teach an alternative way of behaving in human society. Epistemology of many African proverbs can also be situated within this argument: since proverbs as wise sayings are crafted from a people's experiences and values over a long period of time, they are meant to inculcate moral lessons and instruction to young people and those who show interest in the survival of the community. Interestingly, there are a plethora of African proverbs that espouse that corruption of different kinds took place in pre-colonial Africa. ${ }^{40}$

Habib points to the fact that pre-colonial societies had cases of corruption and also dealt with them in tandem with the existing regulations or laws. He adds that in many instances, emblems were mounted conspicuously to constantly serve as deterrence to would-be corrupt people. Such an emblem, he avers, 'functions both as a reminder of his father's corruption and as an admonition to maintain integrity'. ${ }^{41}$ Gennaioli and Rainer also agree that there were instances of corruption in precolonial Africa. According to them, the structure of African societies then helped in no mean way in curbing corruption considerably. They aver that 'the centralized precolonial political institutions of African ethnic groups reduced corruption and fostered the rule of law in colonial and postcolonial Africa' ${ }^{42}$ They maintain that the centralised form of government in pre-colonial Africa also had an influence on the

39 Igboin and Igili 2015. Like father, unlike son: A reconstruction of the meta-life of Unoka in Chinua Achebe's Things fall apart,Southern Semiotic Review 5(1 February 2015): 143-163.

40 Igboin 2014b. African proverbs in the era of globalisation: Losing the soul of African heritage? Paper presented at the Colloquium on Contemporary Issues in Education, Arts, the Social Sciences, and Sciences in Honour of ToyinFalola, held at Tai Solarin University of Education, Ogun State on 27 November 2014.

41 Habib 2010, Skin.A dictionary of cultural and critical theory(2nd edition).Edited by M. Payne and J.R.Barbera (UK: Blackwell Publishing), 651.

42 Gennaioli and Rainer 2005, Precolonial centralization and institutional quality in Africa, 1. 
colonial era and continues to influence post-colonial African societies, not only in areas of provision of common good but also in fighting corruption. How did it work?

Gennaioli and Rainer argue that with centralisation of government in the precolonial era, the incidence of bribes was mainly under the control of the headship of the kingdom. However, in a decentralised structure, each district set and collected bribes. Thus by the time all of those were aggregated, what the decentralised government would have robbed from the citizens, would now at least have doubled what it would have been in a centralised system. From an individual's perspective, a particular decentralised system's corruption might not mean much; for it is possible in such a structure that citizens might want to migrate to other areas that might seem better for their economic engagement. Moreover, the fear of migration and its consequence might caution a decentralised system in exerting bribes or fostering corruption. On the other hand, in a centralised system, what was taken from the people could be ploughed back into the system in the form of provision for education, health and other infrastructure. Gennaioli and Rainer conclude that in post-colonial Africa there is the need to revisit and adopt the centralised form of government that had been practised in pre-colonial Africa, if there is a wish that corruption can be frontally addressed. In their words:

...being so weak, the African national governments are unable to penalize provincial authorities running their own expropriation rackets. As a result, centralized precolonial institutions may have helped to reduce expropriation and improve institutional quality by enforcing collusion among multiple authorities. ${ }^{43}$

This is because 'African countries, where a larger share of the population belongs to ethnic groups with centralized (rather than fragmented) precolonial institutions, have lower corruption and better rule of law', ${ }^{44}$ Bandyopadhyay and Green confirm Gennaioli and Rainer's pre-colonial centralisation theory as having great positive effects on post-colonial Africa. Bandyopadhyay and Green state:

Our results are striking in two ways. First, using a variety of dependent variables, we confirm the Gennaioli and Rainer (2005) hypothesis that pre-colonial centralization is highly correlated with modern-day development outcomes at the district, sub-county, and individual levels. These results are robust to the use of various control variables and clustered standard errors; we also use distance from the ancient capital of Mubende as an instrument and find that most of our results are stronger. Our second finding, however, is that a number of dependent variables are not correlated with pre-colonial centralization, specifically those that measure public goods provision, like immunization and access to hospitals, police, and other public services. Moreover, using Afrobarometer results, we find that there is no relationship between local levels of precolonial centralization and the quality of public services. These findings are thus consistent with a correlation between pre-colonial centralization and private

43 Gennaioli and Rainer 2005, 4.

44 Gennaioli and Rainer 2005, 4. 
rather than public goods, suggesting the persistence of poverty and wealth from the precolonial period to the present. ${ }^{45}$

Gennaioli and Rainer's argument is instructive in post-colonial Africa corruption discourse. In Africa, much attention has always been drawn to the phenomenon of corruption as it affects the central government. Regional or state structure does not receive the same attention. In Nigeria, one can agree with Gennaioli and Rainer that the federal government may not be as corrupt as the state governments when we realise that in the sharing formula of resources, on aggregate, states get much higher allocations than the federal government. The media concentration on the federal government's near neglect of corrupt activities at state and local government levels, clearly depicts their argument. The point is not that the federal/central government is being excused. The inability of the federal government to penalise the state and local levels, stems from both moral and legal issues. If the federal government is perceived as corrupt, it loses the moral power to insist that state and local governments should be corruption-free. As regards legal encumbrance, state governors enjoy constitutional immunity (as in the case of Nigeria), which protects all their actions while in power.

\section{Some acts of corruption: pre-colonial and post-colonial}

In this section, the paper discusses briefly those acts which can be regarded as corrupt in the pre-colonial era and still resonate in post-colonial Africa.

The practice of human ritual as a function of religious devotion has a long history behind it, and it is not peculiar to indigenous African religion. The power of religion is enormous and its influence on adherents cannot be over-emphasised. Such power often does not follow the rudiments of rationality or logic. This is understandable for the simple reason that religions point beyond the goal of rationality - they point to the supernatural. Because of the existential challenges that human beings face, which logic and rationality cannot explain or solve, appeal to religion even in contemporary society seems to be more plausible, and in many ways inevitable. As Sax observes, even those who epistemologically disregard the efficacy of religious rituals have been found to practise them when faced with the labyrinth of life. Consequently, it is not the question of what religious rituals accomplish in human life that matters, but how they do what they do is the domain of scientific episteme. This relates to the practice of human sacrifice believed to be prevalent in pre-colonial Africa, and which has continued to be practised in contemporary Africa. In pre-colonial Africa, human sacrifice could be part of the process of ritualisation of a would-be king. At death, kings were not buried alone in many kingdoms in pre-colonial Africa. They

45 Bandyopadhyay and Green 2012.Pre-colonial political centralization and contemporary development in Uganda, Working Paper No. 141 in the Afrobarometer Working Paper Series, November, 2012. See www.afrobarometer.org 
were buried with servants and a lot of material things believed to be needful for their transition and to settle and retain their position in the community of the ancestors.

Gyekye calls this practice 'false metaphysics" ${ }^{46}$ because he believes that burying human beings with dead kings does not in any way mean that those buried would continue to serve the king in the world beyond. And burying a king without servants also does not prevent the deceased from being what he should become in the hereafter. It was a corruption of human lives, which in contemporary African society would be regarded as a violation of the fundamental human rights of the servants. That being so, the false metaphysics' conceptualisation does not capture the continued practice of human rituals that are common particularly before, during and after electioneering processes in many African countries today. The same belief in the efficacy of human blood in pre-colonial era has continued to be upheld today, just as the secrecy that characterised it before is still being retained, despite the argument that colonialism has disrupted much of the African belief system and practice. One looks in vain, however, to find a link between this practice and colonialism. The argument here is not that colonisers did not kill Africans, but that such killings were not likely ritualistic. They were for political and economic reasons. Since ritual killings still persist in post-colonial Africa, they persist for the same reason they were practised in pre-colonial Africa, which in contemporary discourse is a gross violation of human rights - the right to life. ${ }^{47}$

Another serious human rights abuse and issue of corruption in pre-colonial and post-colonial Africa has to do with slave trade. Slavery and slave trade significantly altered the ego and outlook of many of the West African kings. During this period, internecine wars were multiplied in the scramble for slaves. Some kings got arms from the slave-dealers to conquer their own people and thereafter 'commodified' them. The fact that many of the African kings were willing compradors in this iniquitous transaction, demonstrates a clear psychology of abusers of other people's rights. Coleman appositely elucidates more:

Chiefs and African slave traders readily understood the role of middlemen and brought the slaves to shipside in exchange for European trinkets. Thus they acquired a vested interest in slave traffic and were as much aggrieved by its cessation and their subsequent displacement as were the white dealers. The first Nigerian middle class was liquidated by the abolition of the external slave trade. ${ }^{48}$

Today, human trafficking is a thriving business in many parts of post-colonial Africa. Kidnapping is also prevalent, and can be classified within this category. In precolonial Africa, there were cases of people who were kidnapped and kept in kings'

46 Gyekye 1997.African cultural values: An introduction (Accra: Sankofa).

47 Ajayi 2013. Human sacrifice in contemporary Nigerian politics: Myth or reality. In Nigeria at 50: Politics, society and development.Edited byS. Babatunde, O.E. Victor and O.O. Rasheed(Ibadan: Department of History, University of Ibadan), 248-258. 
palaces for as long as the kings lived. Two interesting post-colonial scenarios are presented here to support our argument. Former governor Theodore Orji of Abia State, Nigeria, some time ago announced amnesty for kidnappers in the state. When nobody embraced the amnesty programme, he accused traditional rulers and political opponents of being behind kidnapping in the state. In fact, it was later discovered that a palace of a traditional ruler was being used as a grove for kidnapping. ${ }^{49}$ The second example has to do with the citizens of Akwa Ibom State, who openly accused the governor of the state as the instigator of kidnapping people. The governor only responded predictably that such allegation was sponsored by his political opponents aimed at smearing the image his government. ${ }^{50} \mathrm{But}$ the critical point being made here is that African leaders, past and present, have been involved in corruption and human rights abuses.

Bribery as an offer, promise or gift to a public official meant to solicit an undue favour is the most commonly identifiable act of corruption. The question is: Were there instances of bribery in pre-colonial Africa? The answer is in the affirmative. There are several narratives of how people - both traditional rulers and subjects in pre-colonial Africa - bribed their way through the process of justice administration. Among the Owan people of Nigeria, for instance, bribery in the case of perversion of justice was/is mildly called ivonu or uhan, which can be translated as 'something offered to close mouth' - that is, a bribe meant to incapacitate a witness or person from speaking the truth in a matter. But the pre-colonial Africans were also very wise and found ways of ascertaining the veracity of people's claim in a matter. This is the concept of swearing to one's hurt and oath-taking. This notwithstanding, priest-craft has negatively affected the efficacy of swearing an oath. The case of Okija shrine where people swore falsely is quintessential. ${ }^{51}$

The case of embezzlement as a corrupt practice can also be established in precolonial Africa. Embezzlement has to do with diversion or misappropriation of public funds. Cases abound in songs and tales of individuals and traditional rulers who embezzled the common wealth of a community or group, as evident in Agbezoro/ Ajoamong the Owan system or Esusu among the Yoruba. Agbezoro is a system of collecting and saving for a group of individuals who subscribed to a system, and their savings were supposed to be given back to them at the end of the season. It is like the modern micro-credit system. ${ }^{52}$ Some had misappropriated or embezzled such funds with the active collaboration of people at the helm of affairs. This phenomenon needs no further explanation in post-colonial African experience.

49 Ayorinde 2010.City of hell.In The News, 11October, 2010, 65.

50 Uffot 2011. Again, kidnappers strike.In Newswatch, January 31, 2011, 27.

51 Igboin 2014c.A critical exploration of African spirituality and democracy in Africa. Journal of Africana Religions 2(4 October 2014): 435-456.

52 Williams 2007, 26. 
Finally, we can cite the act of abuse of position or power as a form of corruption prevalent in both pre-colonial and post-colonial Africa. In African monarchical system, kings and chiefs abused their positions. Such abuse, though, might not be so conceived when hidden under the toga of tradition, which again was backed by religion. Since kings wielded enormous power, the common saying that absolute power corrupts absolutely can hardly be denied as a human phenomenon. The thrust of abuse of power is to gain an undue advantage over the less privileged in any human society. This resonated in the administration of taxation, marrying subjects' wives and daughters without due process, except that a king's thirst must be satisfied by whatsoever he desired, an act that was recognised as traditional, which in reality could have evolved as a consequence of greed. Again such manifest abuse of power by post-colonial leaders cannot be denied.

\section{CONCLUSION}

We started by deconstructing traditional leadership in the light of contemporary reality. The concept of 'traditional' attached to those leaders other than those occupying positions of authority in post-colonial Africa, cannot be argued to strictly conform to the pre-colonial African conceptualisation of it. Rather, the authority to assume what is today called traditional leadership rests solely on the structure of modern democratic leadership, an act that would have been an inconceivable taboo in pre-colonial era. As such the paper argued that contemporary Africa might just have customary leaders whose legitimacy draws conveniently from tradition but wield influence in accordance with the whims and caprices of modern democratic leadership. The mere acceptance of this status is a corruption of tradition. The paper also conceptualised corruption in a creative manner that states that it is a violation of human rights since any act of corruption negatively affects the vulnerable group. This conceptualisation is important because it enables the author to capture and situate such corrupt acts that were prevalent in pre-colonial Africa within the ambit of the corruption discourse. The advantage of this is that it removes it from the precinct of tradition since tradition itself is sometimes crafted to make the effects of some corrupt practices acceptable within a specific community.

The paper disagrees with the Afrocentric school that holds that pre-colonial Africa was completely corruption-free. To uphold the argument of this school would mean that pre-colonial Africans were superhuman and incorruptible. That would be an incorrect assessment of the past. However, the obvious cases of corrupt practices among people independent of the influence of colonialism (this is not to defend colonialism and its ills) effectively make the point that pre-colonial Africa had its stint of corruption. The author may here suggest that the degree and sophistication of corrupt practices might have increased with colonialism, and new ones possibly introduced as a result of contact with the colonisers. The argument of Ali that 
democracy in Africa must countenance the African monarchical system whereby a president could continue until he/she dies in office, is a pungent one. In fact, most African leaders in the post-colonial era have sought both legitimate and illegal ways to sit-tight in power, perhaps as 'democratic kings'. Recourse to the ancestors as imprimatur for actions in the past has continued to resonate in manipulation of religion for political advantage. The same goes for ethnic affinity. Falola observes that most contemporary African leadership 'reinvents older traditions to keep the members of the group together'. ${ }^{33}$ This pursuit of ethnic interest means that 'corruption can be accepted or defended to prevent an ethnic member from being embarrassed by others; and rules of politics and elections can be broken just to get one's ethnic member into power' ${ }^{54}$ There is also a demonstration of how religion in pre-colonial Africa could have been used to sanction many corrupt practices, just as it is being used today to mitigate the intensity of corruption in socio-political and religious circles. The present clearly stems from the past, but the challenge for contemporary is how to possibly emplace credible measures to ensure a different future.

\section{REFERENCES}

Ajayi, A.2013. Human sacrifice in contemporary Nigerian politics: Myth or reality. In Nigeria at 50: Politics, society and development. Edited by S. Babatunde, O.E. Victor and O.O. Rasheed.Ibadan: Department of History, UI, 248-258.

Akpotor, S.2003. Corruption: The civil society and government. In Philosophy and politics: Discourse on values, politics and power in Africa. Edited by M. Dukor.Lagos: Malthouse Press.

Antwi-Danso, V. 2005.Development theory: Conjectures and refutations in the African context, paper delivered at the 10th International Conference of the Seminary of All Saints, Ekpoma, Edo State, Nigeria, 25-29 October, 2005.

Ayorinde, O.2010. City of Hell. In The News, 11 October, 2010.

Bandyopadhyay, S. and Green, E. 2012.Pre-colonial political centralization and contemporary development in Uganda. Working Paper No. 141 in the Afrobarometer Working Paper Series, November, 2012. www. afrobarometer.org

Coleman, J.S. 1958. Nigeria: Background to nationalism. Benin City: Broburg\&Wistrom.

Falola, T. 2015.Natural and cultural heritage for sustainable development. 2nd Dr John A. Odeyemi Annual Lecture, Obafemi Awolowo University, Ile-Ife, 14th May, 2015.

Gennaioli and Rainer.2005. Precolonial centralization and institutional quality in Africa.

Girling, J. 1997. Corruption, capitalism and democracy. London: Routledge.

Gyekye, K, 1997. African cultural values: An introduction. Accra: Sankofa.

53 Falola2015.Natural and cultural heritage for sustainable development, the 2nd Dr John A. Odeyemi Annual Lecture, Obafemi Awolowo University, Ile-Ife, 14th May, 2015, 50.

54 Falola2015, 40-41. 
Gyekye, K. 2003. Political corruption: A philosophical inquiry into a moral problem. In Philosophy and politics: Discourse on values, politics and power in Africa. Edited by Dukor. Lagos: Malthouse Press.

Habib, M.A.R.2010. Skin.A dictionary of cultural and critical theory (2nd edition).Edited by M. Payne and J.R. Barbera. UK: Blackwell Publishing.

Hrituleac, A. 2011.The effects of colonialism on African economic development: A comparative analysis between Ethiopia, Senegal and Uganda. MSc. dissertation submitted to Aarhus University, Business and Social Sciences.http://korrectgossips.com/gossips/if-you-dontvote-ambode-thats-your-end-oba-of-lagos-warns-igbos/

Igboin, B.O. 2011. Political onanism and scepticism in a democratic country. LUMINA, 22(1 March 2011): 234-249.

Igboin, B.O. 2013. Cosmotheandrism and traditional African leadership: The future left behind? Paper presented at the International Conference of African Studies, on the theme: Revisiting the First International Congress of Africanists in a globalised world. Institute of African Studies, University of Ghana, Legon 24-26 October, 2013.

Igboin, B.O. 2014a. Revisiting the basis of the metaphysics of ancestorship in contemporary Africa. In Death and life after death in African philosophy and religions: A multidisciplinary engagement. Edited by Danoye Oguntola-Laguda. Harare: Africa Institute for Culture, Dialogue, Peace and Tolerance Studies, 79-97.

Igboin, B.O.2014b. African Proverbs in the era of Globalisation: Losing the Soul of African Heritage? presented at the Colloquium on Contemporary Issues in Education, Arts, the Social Sciences, and Sciences in Honour of Toyin Falola, held at Tai Solarin University of Education, Ogun State on 27th November, 2014.

Igboin, B.O. 2014c. A critical exploration of African spirituality and democracy in Africa. Journal of Africana Religions 2(4 October 2014): 435-456.

Igboin, B.O.2015.Afrocentrism: Recalling the will of the past for the future. Paper presented at the Conference organised by the Faculty of Letters and Social Sciences, University of Douala, Republic of Cameroon on the theme: A young Commonwealth, cultural heritage and commonwealth values, 11-14 March, 2015.

Igboin, B.O. and Igili, O.J. 2015. Like father, unlike son: A reconstruction of the meta-life of Unoka in Chinua Achebe's Things fall apart. Southern Semiotic Review 5(1 February 2015): 143-163.

International Council on Human Rights Policy and Transparency International, Corruption and Human Rights: Making the Connection Switzerland, International Council on Human Rights Policy, 2009.

Keulder, C.2008. Traditional Leadership. In State, society and democracy: A reader in Namibian politics.Edited by C. Keulder. Gamsberg: Macmillan.

Norris, C.2010. Philosophy of law.In A dictionary of cultural and critical theory (2nd edition). Edited by M. Payne and J. R. Barbera. UK: Blackwell Publishing.

Nunn, N.2003.The legacy of colonialism: A model of Africa's underdevelopment. Department of Economics and Institute for Policy Analysis, University of Toronto.

Ogungbemi, S. 2007.Philosophy and development. Ibadan: Hope Publications. 
Onimhawo, J.A. and Igboin, B.O. 2008.ONANISM: A moral evaluation of political power retention in Nigeria. Monograph series 1,Ekpoma.

Uffot, E.2011.Again, kidnappers strike. In Newswatch, 31 January, 2011.

Vengeyi, O.2015.Fr. Gonzalo da Silveira's evangelisation strategies as roots for disempowerment: Lessons for Africa from Zimbabwe's history. Journal of African Culture and International Understanding 11(January-June 2015): 27-28.

Williams, I.2007. Can our culture and traditions overcome corruption? CBAAC Occasional Monograph No. 1, Lagos. 